\title{
Error Analysis of Junior High School Students' Vowel Pronunciation
}

\author{
Qinhua Ji \\ School of Humanities, Tiangong University, Tianjin, China \\ Email: qinhuaji2020@163.com
}

How to cite this paper: Ji, Q.H. (2021) Error Analysis of Junior High School Students' Vowel Pronunciation. Open Access Library Journal, 8: e7689.

https://doi.org/10.4236/oalib.1107689

Received: June 24, 2021

Accepted: July 18, 2021

Published: July 21, 2021

Copyright $\odot 2021$ by author(s) and Open Access Library Inc.

This work is licensed under the Creative Commons Attribution International License (CC BY 4.0).

http://creativecommons.org/licenses/by/4.0/ (c) (i) Open Access

\begin{abstract}
Mobile learning has brought significant changes in English language teaching and learning. Fun Dubbing, as one of the Apps to learn English pronunciation, has drawn extensive attention among students. This paper aims to analyze the errors that junior high school students make in Fun Dubbing based on Error Analysis. The results showed that negative transfer of Hanyu Pinyin, wrong distinction between short vowels and long vowels and lack of knowledge about confusing phonemes are three major causes of errors. In addition, some suggestions are provided for English language learners.
\end{abstract}

\section{Subject Areas \\ English Language Teaching and Learning}

\section{Keywords}

Error Analysis, Fun Dubbing, Vowels, Junior High School Students

\section{Introduction}

Mobile learning, a kind of learning that can take place at any time and any place using mobile devices, has brought significant changes in education, especially in English language teaching and learning. Various kinds of online classes or apps are developed and proven efficient for four skills: listening, speaking, reading and writing. The language input becomes more dynamic and students can get enough exposure to native English. Early in 1989, American phonetician A. C. Gimson has pointed out the significance of pronunciation "for one person to master a language, he must acquire phonological knowledge 100\%, grammar to $50 \%-90 \%$ while vocabulary to $1 \%$ is enough" [1]. Thus pronunciation is to be focused. Most of researches have been done to analyze the errors of college stu- 
dents or vocational students and offer pedagogical suggestions to teachers, such as Chen Chunmei and He Anping's "An Analysis of Oral Segmental Errors of Advanced English Learners-A corpus Based Study" and Luo Han and Zhang Wenzhi's "Analysis of College Students' English Phonetic Errors". Few of them pay attention to middle school or primary school students. Thus this paper aims to analyze the errors that junior high school students make in dubbing based on Error Analysis. Corpus from Fun Dubbing are selected and then analyzed. Three questions are to be answered. What are the errors in pronouncing vowels? What are the influencing factors leading to wrong pronunciation? And what suggestions can be offered to English learners? Furthermore, this paper can be divided into four parts. A brief introduction of research background is to be firstly displayed. Then theoretical framework and literature review including studies on EA at home and abroad are introduced. The third part covers analysis of errors in junior high school students' dubbing. Then the conclusion is drawn.

\section{Literature Review}

In this part, theoretical framework of Error Analysis (EA) including the distinction between errors and mistakes, types of errors are firstly clarified. Then studies of EA at home and abroad especially EA in English pronunciation are to be displayed.

EA is the first approach to the study of SLA (Second Language Acquisition) which includes an internal focus on learner's creative ability to construct language. It is based on the description and analysis of actual learner errors in L2, rather than on idealized linguistic structures attributed to native speakers of L1 and L2 (as in CA) [2]. Firstly, the distinction between errors and mistakes should be illustrated. Mistakes often occur when learners fail to perform their competence. The learners have already learned the knowledge or skill but simply fail to function correctly due to lack of attention or other factors. However errors usually arise from learner's lack of knowledge. It represents a lack of competence. Then in term of source of errors, it can often be divided into interlingual errors and intralingual errors. The former one refers to errors resulting from negative transfer of L1 to L2 while the latter refers to errors in L2 that are not due to interference from L1. These are also sometimes termed development errors, meaning that they represent incomplete learning of L2 rules or overgeneralization of them.

\subsection{Studies on EA Abroad}

In 1967, S. Pit Corder's article on "The significance of learners' errors" made EA as an approach in SLA in which L2 learners' errors are not as "bad habits" to be eradicated, but as sources of insight into the learning process. He indicated that errors provide evidence of the course of L2 development, and of the strategies or procedures the learner is using in his "discovery of the language". That is to say, errors are windows into language learners' mind. He also claimed that making 
errors is significant because it is part of the learning process itself. And errors are thus a sign that the learner is (perhaps unconsciously) exploring the new system rather than just experiencing "interference" from old habits [3].

In 1994, Ellis put forward the procedures for analyzing learner errors in the book The Study of Second Language Acquisition. It mainly includes five steps: collection of a sample of learner language, identification of errors, description of errors, explanation of errors and evaluation of errors [4].

Many experts and scholars have carried out quite a lot of researches both theoretically and empirically on EA and have yielded fruit results. Meanwhile, EA has been accepted by domestic scholars and widely used in multiple fields, especially in language teaching and learning.

\subsection{Studies on EA at Home}

In 1998, Du Xiaomei illustrated some problems of pronunciation of English teachers in junior middle school in the paper "An Analysis of Some Perfections in Pronunciation of English Teachers in Junior Middle School'. It generally includes three aspects: poor pronunciation, unsmooth language flow and weird sentence stress and intonation [5].

In 2000, Liu Jian analyzed and elaborated typical errors of middle school students' pronunciation from three perspectives phoneme, spelling and intonation in the paper "A Typical Error Analysis of Middle school Students English Pronunciation under the influence of Chinese" [6].

In 2006, Luo Han and Zhang Wenzhi illustrated the errors of freshman in a foreign language department from two aspects pronunciation, stress, rthyme and intonation and put forward some suggestions for English pronunciation teaching in the paper "Analysis of College Students' English Phonetic Errors" [7].

In 2008, Chen Chunmei and He Anping summarized the overall problems of Vowels and consonants of Chinese college students by retrieving the Chinese sub-corpus of the spoken Corpus of international English learners and the spoken corpus of college English learners in the paper "An Analysis of Oral Segmental Errors of Advanced English Learners - A corpus Based Study" [8].

In 2009, Gao Lin and Deng Yaochen studies word stress misplacement in the sample oral reading in the Chinese college non-English majors and in COLSEC (College Learner Spoken English Corpus). The research showed that the stress displacement of polysyllabic words is the most common, and the tendency of the stress to be mispronounced in the second syllable is also obvious [9].

In 2010, Zhou Weijing, Shao Pengfei and Chen Hong published the paper Perception of RP English Vowels by Chinese College English Majors. The results showed that correct perception rate of the vowels is $75 \%$ with back vowels ranking top (80\%) and central vowels bottom (70\%). The best perceived vowels are [i:] (96\%), [u:] (90\%), [i] (89\%) while the least perceived are [e] (55\%), [æ]

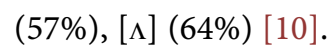

In 2012, Gao Ge and Qin Hongwu published the paper The Influence of Chinese Experience on English Phonetic Acquisition at Suprasegmental Level. The 
result showed that the second syllabus of English words is often analogically stressed by Chinese EFL learners. And the rising tones produced by Chinese EFL learners differ greatly from those by the English native speakers [11].

In 2019, Wen Bin and Chen Zisang presented a model through error analysis of pronunciation, especially in vowels in the paper " $A$ Study of English \& Chinese Phonetic Contrastive Pedagogical Model and Its Feasibility-based on Contrast of Vowels" [12].

From above, it can be seen that EA is closely combined with language teaching and learning. Most of studies are mainly empirical. And domestic scholars have discussed phonetics from both segmental and supersegmental including syllabus, stress, pitch and intonation. The research subjects are mainly college students whether they are English majors or non-English majors. Less attention is paid to primary school students and middle school students. Thus it is necessary to analyze the errors that junior school students make in dubbing based on EA.

\section{Research Procedures}

In this part, Fun Dubbing is firstly introduced. And then research method and statistical analysis are to be displayed in which influential factors of errors are displayed.

\subsection{Fun Dubbing}

Fun Dubbing is a version of English dubbing learning software officially launched by English Qu Dubbing. It is free, easy to operate, and highly compatible. It can run on mobile phones and computers equipped with simulators. Various materials, different phonetic preferences, the speed of speech are taken into consideration. Besides, feedback is also provided. Moreover, several researches have been done to certify its proficiency. For example, in 2020, Qu Dianning, Su Yi and Lu Xiaofei indicated that "online dubbing provides the learners authentic multimodal input and L2 learners obtains enough affordance through interacting with the L2 context in the course of online imitation and dubbing" in the paper "The Influence of Online Dubbing on the Intelligibility and Comprehensibility of Pronunciation of Chinese EFL learners" [13]. Thus Fun dubbing indeed promote students' self-directed learning and it is necessary and efficient to analyze the errors that students may make in the process of dubbing.

\subsection{Research Methods}

Four short videos about Harry Potter were selected for dubbing shown in Appendix 1. And preferential monophthongs in subtitles are in bold. And 20 anonymous Chinese students of junior two are as research subjects numbered Arabic numerals 1, 2, 3 .. 20 showed by horizontal axis in Appendix 2. Their dubbing are carefully analyzed under the guidance of EA. [i:] [i] [e] [æ] [ə:] [ə] [ $\Lambda$ ] [o] [o:] [u:] [u] [a:] is labeled 1, 2, $3 \ldots 12$ respectively. Some phonetic alphabets in Chinese (Hanyu Pinyin) are explained in the annotation in Appendix 2. 


\subsection{Statistical Analysis}

Table 1 and Table 2 are collected from the data shown in Appendix 2.

Table 1. Interlingual \& intralingual errors in pronouncing Monophthongs.

\begin{tabular}{|c|c|c|c|}
\hline \multirow{2}{*}{$\begin{array}{l}\text { Vowel } \\
\text { Types }\end{array}$} & \multicolumn{3}{|l|}{ Monophthong } \\
\hline & Types & Frequency & Percentage (\%) \\
\hline $\begin{array}{l}\text { Interlingual } \\
\text { errors }\end{array}$ & $\begin{array}{l}1-21,2-1,2-21,3-25,4-25,6-5,7-24 \\
8-22,9-8,10-23,10-24,11-10,12-24\end{array}$ & 98 & $56.6 \%$ \\
\hline $\begin{array}{l}\text { Intralingual } \\
\text { errors }\end{array}$ & $\begin{array}{c}2-3,3-4,3-6,4-3,4-7,4-12,5-10,7-10 \\
\quad 7-12,8-9,8-11,10-11,10-12,12-3\end{array}$ & 75 & $43.4 \%$ \\
\hline
\end{tabular}

Table 2. Errors in pronouncing Monophthongs.

\begin{tabular}{|c|c|c|c|}
\hline Types of error & Frequency & Percentage $1(\%)$ & Percentage $2(\%)$ \\
\hline $1-21$ & 14 & $35 \%$ & $9 \%$ \\
\hline $2-1$ & 22 & $37 \%$ & $14 \%$ \\
\hline $2-21$ & 8 & $13 \%$ & $5 \%$ \\
\hline $2-3$ & 1 & $3 \%$ & $1 \%$ \\
\hline $3-4$ & 2 & $5 \%$ & $1 \%$ \\
\hline $3-6$ & 2 & $5 \%$ & $1 \%$ \\
\hline $3-25$ & 2 & $5 \%$ & $1 \%$ \\
\hline $4-3$ & 6 & $15 \%$ & $4 \%$ \\
\hline $4-7$ & 7 & $18 \%$ & $4 \%$ \\
\hline $4-12$ & 1 & $3 \%$ & $1 \%$ \\
\hline $4-13$ & 2 & $5 \%$ & $1 \%$ \\
\hline $4-25$ & 1 & $3 \%$ & $1 \%$ \\
\hline $5-10$ & 10 & $25 \%$ & $6 \%$ \\
\hline $6-5$ & 1 & $3 \%$ & $1 \%$ \\
\hline $7-10$ & 14 & $35 \%$ & $9 \%$ \\
\hline $7-12$ & 5 & $13 \%$ & $3 \%$ \\
\hline $7-24$ & 2 & $5 \%$ & $1 \%$ \\
\hline $8-9$ & 8 & $20 \%$ & $5 \%$ \\
\hline $8-11$ & 2 & $5 \%$ & $1 \%$ \\
\hline $8-22$ & 6 & $15 \%$ & $4 \%$ \\
\hline $9-8$ & 24 & $60 \%$ & $15 \%$ \\
\hline $10-11$ & 2 & $5 \%$ & $1 \%$ \\
\hline $10-12$ & 1 & $3 \%$ & $1 \%$ \\
\hline $10-24$ & 5 & $13 \%$ & $3 \%$ \\
\hline $10-23$ & 2 & $5 \%$ & $1 \%$ \\
\hline $11-10$ & 7 & $18 \%$ & $4 \%$ \\
\hline $12-3$ & 12 & $30 \%$ & $7 \%$ \\
\hline $12-24$ & 4 & $10 \%$ & $2 \%$ \\
\hline
\end{tabular}

Note: Percentage 1: The proportion of students who make errors. Percentage 2: The proportion of each item in all errors. 
In the above table, it can be seen that in Table 1, students' pronunciation errors caused by negative transfer of Chinese account for 56.6\% while errors caused by the interference of similar sounds within English account for $43.4 \%$. Thus negative transfer of native language Chinese is the major cause of errors. And data about errors in pronouncing monophthongs is illustrated respectively in Table 2.

\subsubsection{Interlingual Errors}

Firstly, interlingual errors are to be analyzed detailedly and respectively. Influenced by native language, $35 \%$ of students pronounce the front vowel [i:] as "yi" in Chinese phonetic alphabet. The place of tongue of "yi" is a little higher than [i:]. $5 \%$ of students pronounce [e] and $3 \%$ of the students pronounce [æ] as "ai" like “哀” in Chinese. When “哀” is pronounced, the mouth is wider than that of [e] and smaller than that of [æ]. And 5\% of students pronounce the central vowel $[\Lambda]$ as “a” like “啊” in Chinese because mouth is wider and tongue is back. Besides 15\% of students pronounce the back vowel [u:] as “u” like “乌” in Chinese because tongue is too back. $5 \%$ of students pronounce [0:] as "o" just like “哦” in Chinese. What's more, $10 \%$ of students pronounce the back vowel [a:] as “a” like “啊” in Chinese. Therefore, it can be found that native language Chinese often transfers negatively to foreign language learning.

It can also be clearly seen that students often fail to distinguish long vowels and short vowels. For example, $37 \%$ of students read [i] as [i:]. $60 \%$ of students misread [u] as [u:]. Besides, $18 \%$ of students read [o] as [o:].

Therefore it can be concluded that there are three main types of negative transfer of Chinese in pronouncing monophthongs: length, slide and tongue. In English, length is one of distinguishing characteristics that can be used for identifying different words. However, in Chinese, every syllabus is of the same length. If the syllabus is prolonged, it is commonly used for expressing emotions or pragmatic use. Thus influenced by native language Chinese, students often prolong the short vowel or shorten the long vowels, such as $1-21,2-1,6-5,9$ 8 , and $11-10$.

The second one is slide. When students speak English, especially monophthongs, there is not slide. Nevertheless when students speak Chinese, there is a slight slide which is of different levels (compared to diphthongs in English). For example, in 3 - 25 [e] itself doesn't slide, but when it is pronounced as "ai" like “哀” in Chinese, there is slide.

The third one is tongue. It is extremely confusing to pronounce similar monophthongs because their tongue position is alike but slightly different. In addition, the change of tongue position will lead to the alignment of the mouth and even the shape of lips. For example, in $7-24$ central vowel $[\Lambda]$ is pronounced as “a” like “啊” in Chinese in which mouth is wider and tongue is back.

\subsubsection{Intralingual Errors}

Intralingual errors are analyzed respectively. The errors of front vowels are firstly displayed. It can be seen that $3 \%$ of students pronounce [i] as [e] because 
the place of articulation is back. $5 \%$ of students mispronounce [e] as [æ]. 15\% of students pronounce $[æ]$ as [e]. Moreover, $18 \%$ of students pronounce $[æ]$ as $[\Lambda]$ while $3 \%$ of students read $[æ]$ as [a:]. According to the data, [e] [æ] and $[\Lambda]$ are the most confusing. Students do not distinguish their tongue and place of articulation.

Then errors of central vowels are illustrated in details. It can be clearly found that $25 \%$ of students pronounce [ə] as [०:]. And $35 \%$ of students pronounce $[\Lambda]$ as [o:] while $13 \%$ of students $[\Lambda]$ as [a:].

What's more, errors of back vowels are to be presented. $20 \%$ of students pronounce [u:] as [u] while $3 \%$ of students [u:] as [o]. $5 \%$ of students pronounce [o:] as [0] while $3 \%$ of the students read [o:] as [a:]. In addition, $30 \%$ of pupils read [a:] as [e].

From the above analysis, it can be found that negative transfer of native language Chinese is the major cause of phonetic errors. The length, slide and tongue may influence the pronunciation of vowels. The interlingual errors can be mainly classified into two types. Some phoneme is pronounced as Hanyu Pinyin. And some short vowels and long vowels can't be distinguished. As for intralingual errors, students may fail to master the tongue and place of articulation of phonemes so that they can't correctly pronounce some phonemes. Some of them are confusing. Here some advice is provided for junior school students. Firstly, identify the differences of phonemes in English and alphabets in Hanyu Pinyin. And try to minimize the effect of the negative transfer of Chinese. Secondly, identify confusing phonemes, especially its tongue and place of articulation. Thirdly, before dubbing, try to look up the pronunciation in the dictionary and make sure every word is correctly pronounced. Through above procedures, students can better pronounce and dub the video.

\section{Conclusion}

This paper has discussed the errors that junior high school students make in Fun dubbing based on the Error Analysis. And short videos of famous movie Harry Potter are selected as its materials. Through analysis, three questions are to be answered. It can be found that phonetic errors can be divided into two types: interlingual errors and intralingual errors. And the former can be classified into two types: pronunciation of Hanyu Pinyin and wrong distinction between short vowels and long vowels. Negative transfer of Chinese is the major cause of interlingual errors. The length, slide and tongue may influence the pronunciation of vowels. As for intralingual errors, students fail to master the tongue and place of articulation of confusing phonemes. Some suggestions can be given to Chinese junior school students: First of all, identify the differences of phonemes in English and alphabets in Hanyu Pinyin; secondly, identify confusing phonemes, especially its tongue and place of articulation; thirdly, before dubbing, try to look up the pronunciation in the dictionary and make sure every word is correctly pronounced. Through above procedures, students can improve their pronuncia- 
tion, especially vowels. On the other hand, this study also has its limitations. The size of sample is small and identification of students' pronunciation is not so objective which needs to be further optimized.

\section{Conflicts of Interest}

The author declares no conflicts of interest.

\section{References}

[1] Gimson A.C. (1977) An Introduction to the Pronunciation of English. English Language Book Society and Edward Arnold, London, 225.

[2] Saville-Troike, M. (2008) Introducing Second Language Acquisition. Foreign Language Teaching and Research Press, Beijing, 37.

[3] Corder, S.P. (1967) The Significance of Learners' Errors. International Review of Applied Linguistics, 5, 161-170. https://doi.org/10.1515/iral.1967.5.1-4.161

[4] Ellis, R. (1985) The Study of Second Language Acquisition. Oxford University Press, Oxford.

[5] 杜晓梅. 初中英语教师语音现状的分析与思考[J]. 教学研究, 1998(4):255-256.

[6] 刘健. 中学生英语语音受汉语影响的典型错误分析 [J]. 教学与管理, 2000(7): 62-63.

[7] 骆涵, 张文芝. 大学生英语语音错误分析[J]. 中国大学教学, 2006(7): 60-61.

[8] 程春梅, 何安平. 高级英语学习者口语音段错误分析一一一项基于语料库的研究 [J]. 解放军外国语学院学报, 2008(1): 38-42+70.

[9] 高琳, 邓耀臣. 中国大学生英语单词重音位移现象研究一一一项基于语料库的研 究[J]. 外语界, 2009(3): 10-16+44.

[10] 周卫京, 郡鹏飞, 陈红. 英语专业大学生对 RP 英语元音感知的实证研究 [J]. 解放 军外国语学院学报, 2010, 33(6): 45-49+128.

[11] 高歌, 秦洪武. 超音段层面上汉语经验对英语语音习得影响的实验研究[J]. 山东 外语教学, 2012, 33(6): 52-57.

[12] 文兵, 陈梓桑. 英汉语音对比教学模型及其可行性研究一一以元音对比为例 [J]. 汕头大学学报(人文社会科学版), 2019, 35(1): 46-55+95.

[13] 屈典宁, 苏怡, 陆小飞. 在线配音对中国英语学习者语音清晰度与可理解度的影 响[J]. 外语教学, 2020, 41(6): 77-82. 


\section{Appendix 1}

\section{Harry Potter}

1)

- The only thing that I want to worry about is this. The Golden Snitch.

- I like this ball

- You like it now. Just wait. It's wicked fast and damn near impossible to see.

- What do I do with it?

- You catch it, before the other team's Seeker. You catch this, the game's over. You catch this, Potter, and we win.

2)

- What are those?

- You better take this

- Careful now, it's coming back

- Not bad, Potter

- You'd make a fair beater

- What was that?

- Bludger. Nasty little buggers

3)

- Qudditich is easy enough to understand. Each team has seven players.

Three chasers, two beaters, one keeper and a seeker. That's you.

- There are three kinds of balls. This one's called a Quaffle.

The chasers handle the quaffle, and try to put it through one of those three hoops. The keeper, that's me, defends the hoops. With me so far?

- I think so.

4)

- You did everything you could. No one could win against that old hag

- Even Dumbledore didn't see this morning.

- Harry, if it's anyone's fault, it's ours.

- Yeah, we talked you into it

- Yeah, but I agreed it. I tried so hard to help, and all it's done is making it worse. Anyway, that doesn't matter anymore. Because I don't want to play anymore. All it does is make you care too much. And the more you care, the more you have to lose. So maybe it's just better to...

- To what?

- To go it alone. 


\section{Appendix 2}

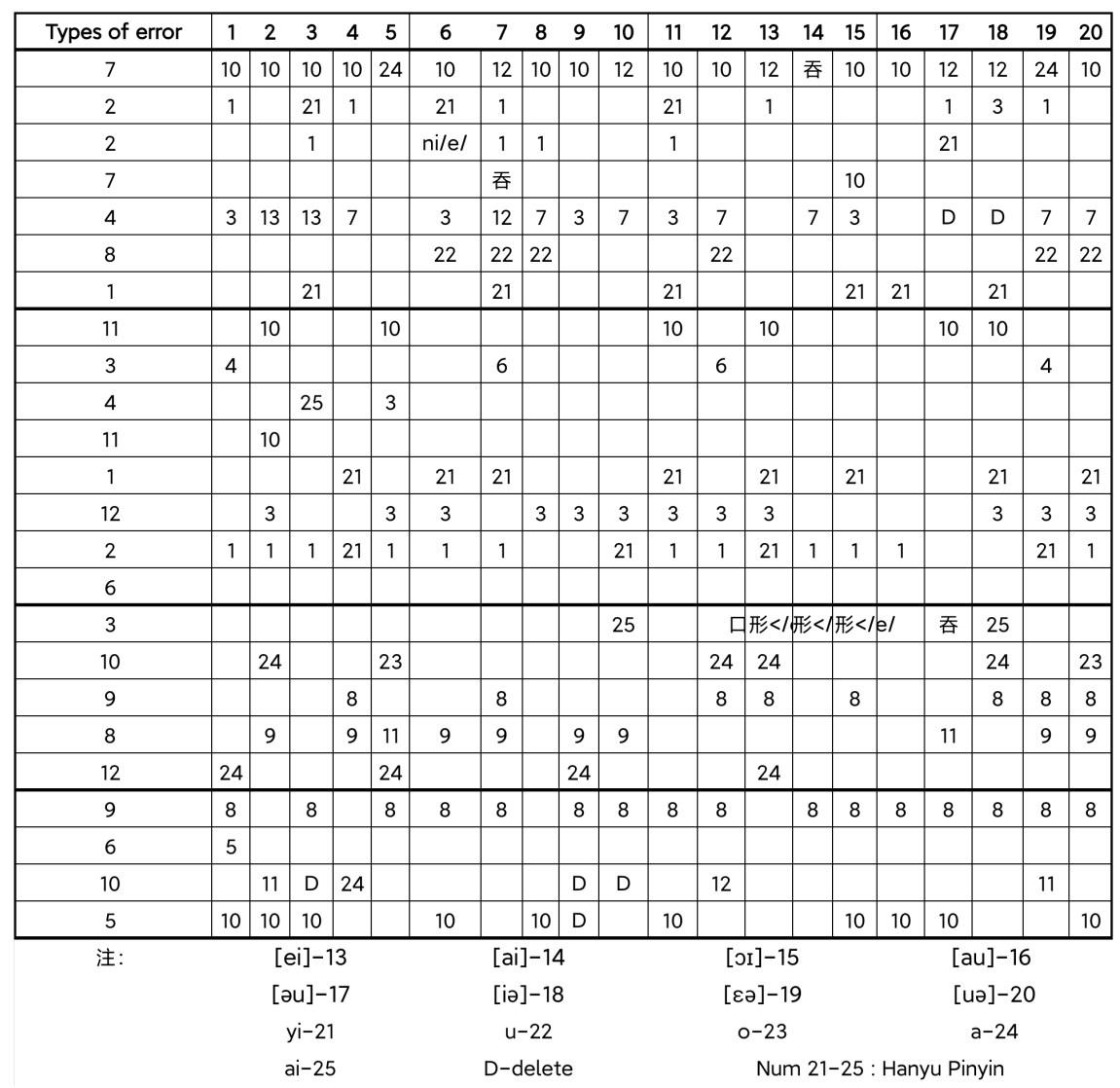

